How to cite: Harbulakova, V.O., Zelenakova, M., Sugarekova, M. (2019) Assessment of the Preparedness for Flood Protection of Municipalities in Presov Region Based on the Questionnaire Survey. 2019"Air and Water - Components of the Environment" Conference Proceedings, Cluj-Napoca, Romania, p. 99-108, DOI: 10.24193/AWC2019_10.

\title{
ASSESSMENT OF THE PREPAREDNESS FOR FLOOD PROTECTION OF MUNICIPALITIES IN PRESOV REGION BASED ON THE QUESTIONNAIRE SURVEY
}

\section{Vlasta Ondrejka HARBULAKOVA ${ }^{1}$, Martina ZELENAKOVA ${ }^{1}$, Maria SUGAREKOVA ${ }^{1}$}

\section{DOI: 10.24193/AWC2019_10}

\begin{abstract}
Monitoring of floods with the ultimate aim of predicting them, and managing the rescue and rehabilitation operations during and after the calamity, has been a subject of discussion of various forums. The state of the flood occurrence and implementation of flood control measures in the municipality was identified in the questionnaire survey. Questionnaire survey distributed to the municipalities in Presov region in eastern Slovakia deals with general information about the municipality, environmental damages caused by floods and the current state of preparedness of municipalities for floods. Some questions are oriented on preparedness of plan of flood rescue work and flood security work in the municipalities. From the wide range of questions in the questionnaire survey six of them, aimed on assessment of the preparedness of flood protection measurements are presented in paper. The questionnaire survey was intended to help municipalities to deepen knowledge levels in the area of flood protection measures. Many of them have expressed interest in the feedback of the results of the questionnaire survey to be sent to them. Based on the results obtained and the evaluations, they can make a significant contribution to increase the flood protection, especially in areas affected by this phenomenon.
\end{abstract}

Keywords: flood damages, flood protection measures, flood rescue plan, flood security plan

\section{INTRODUCTION}

The vulnerability of a village or town to flooding depends on multiple factors, not only climatological, but also local geographical and morphological, socioenvironmental characteristics, etc. (EEA Report, 2017). Controlling or reducing flood risk is carried out by implementing so-called flood protection measures, which are roughly divided into non-structural and structural flood protection measures.

Flood protection measures are being implemented by various competent institutions, most of them as public sector bodies (state administration bodies, local communities, etc.). In Slovakia, the Ministry of the Environment, the Slovak Environment Agency, the Slovak Water Management company and the

\footnotetext{
${ }^{1}$ Techical University of Kosice, Faculty of Civil Engineering, Vysokoskolska 4, 04200 Kosice vlasta.harbulakova@gmail.com martina.zelenakova@tuke.sk marya.sugi@gmail.com
} 
Administration of the Republic of Slovakia for Civil Protection and Disaster Management are responsible for implementing most of the flood protection measures at the state level. Non-structural measures include, for example, forecasting of floods, establishment and management of flood risk data, prediction of floods, flood warning or preparation of flood protection and rescue plans (frisco-project.eu, 2019). One of the most critical elements of flood rescue given its demand for a multi-agency approach is pre-event relationships. No written plan in the world will ensure successful rescues if at the incident-ground, personalities collide. There is strong merit to form a flood rescue working group under the auspices of responsible authorities (Glassey, 2008). The second most critical element of flood rescue is predeployment. Flood rescue incidents quickly unfold, often with fatal outcomes. It is imperative that flood rescue assets are pre-deployed and staged close to high risk areas during flood events.

The floods have occurred in Slovakia periodically every two years since 2000 . The development of the precipitations in Slovak republic in period from 1881 to 2010 is shown in Figure 1 (MoE, 2010).

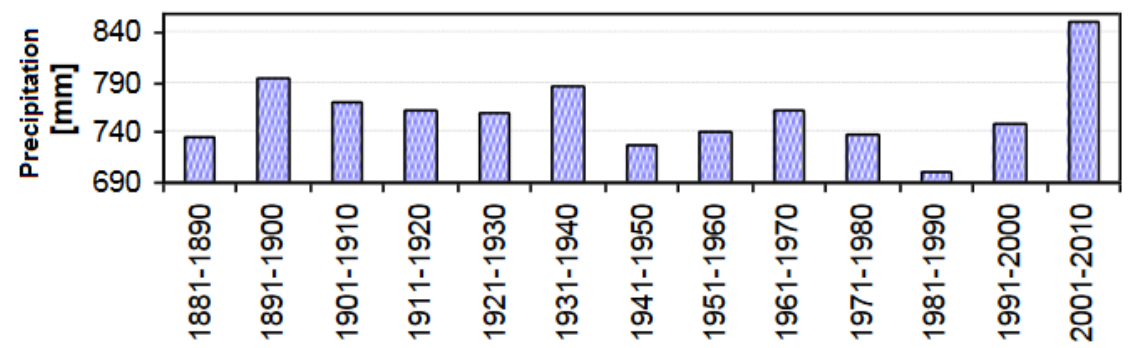

Fig. 1. The average precipitations amount in Slovak republic in period from 1881 to 2010

The analyses of the volume of precipitation, runoff, their time and the place of the occurrences confirm that catastrophic flood events - both in large scale areas and in small river basin - are caused by an unusually large sum of high intensity precipitation in the areas where the basins are already saturated from previous rains. Last 15 years were exceptionally rich in precipitation (MoE, 2010).

During these events two major floods were registered in 2002 which were independent one to another (MoE, 2013). In March, floods occurred in the upper part of the Danube River Basin. Increased precipitation combined with spring snowfalls caused a flood wave with a flow $Q_{\max }=8474 \mathrm{~m}^{3} \cdot \mathrm{s}^{-1}$. The second wave occurred in August at the Devin hydrometric station with flow $Q_{\max }=10,390 \mathrm{~m}^{3} \cdot \mathrm{s}^{-1}$. From the historical point of view, it is the third largest flow, immediately after floods registered in year 1899 and 1954 (MoE, 2013).

In 2004 several flood caused by heavy precipitation in the river basins of rivers in eastern Slovakia (basin Topla, Ondava, Torysa, Poprad and Hornad) were monitored. During the same flood on Ondava River, about 30 meters long section 
of the dyke was torn off and the inhabitants of Malcice village had to be subsequently evacuated.

The high intensity of precipitation it the end of May and in the beginning of June 2010 leads to floods with disastrous consequences in whole Central Europe. Injured areas were also Czech Republic, Poland, Hungary and Slovakia where the floods hit the same time (MoE, 2013). The flood that occurred in 2010 is one of the largest in the last two decades.

Presov region located in eastern Slovakia is extremely exposed to floods mainly in last decades (Zelenakova, 2011; Blistanova et al., 2016; Harbulakova et al., 2017). The questionnaire survey contained questions about the inhabitants in investigated region, about the changes in flood situation in last 10 years, about the implementation of the flood protection measures in connection to the probability of flood occurrence in the future. Last two questions were aimed on the current state of the preparedness of the plans of flood security and flood rescue works.

\section{STUDY AREA}

In the territory of the Slovak Republic the floods occurred in three waves. More than 33,000 inhabitants were affected, with almost 28,000 dwellings and 7,000 nonresidential buildings flooded with water and mud. The first wave hit the northwest and eastern part of the territory. In the East of Slovakia, two dykes were torn off at the time and one bridge was demolished. The third flood activity degree was announced on the rivers Hornad, Torysa, Ida, Bodva, Rožňava, Olsava and Vyrava (rivers of Eastern Slovakia).

The second wave affected mainly Eastern Slovakia, where the third flood activity degree was announced up to nine rivers. An extraordinary situation was reported in the Trebisov district. There was a danger of a risk of breaking the dykes. Several inhabitants from the districts of Kosice-okolie, Stara Lubovna, Kezmarok, Bardejov had to be evacuated. (SHMI, 2010).

The third wave took place in mid-August. The territory of Upper Nitra and Turec was affected. The flood that occurred in 2010 was one of the most devastating floods in the past 100 years. The damages were estimated at approximately 90 million euros. In the village Nizna Mysla in Kosice-district there was a landslide, which resulted in damage of the new family houses. Damages were not caused on real estate or movable properties only, but also on their mental health. During these floods also casualties were recorded.

The Presov region is the second largest municipality region with an area of 8,973 $\mathrm{km} 2$ and is divided into 13 districts. It occupies $18.3 \%$ of the country's area. In the south, it borders on the Kosice region, in the southwest with the Banskobystricky region, on the west with the Zilina region. The state border with Poland is also at the border of the region, as well as in the east with Ukraine as is presented in Figure 2 (Presov self-governing region, 2019).

The largest districts of the Presov region are the districts of Poprad, Bardejov and Presov. The Presov Region consists of 665 municipalities, of which 23 are towns and 642 belong to the villages (Sugarekova, 2018). 


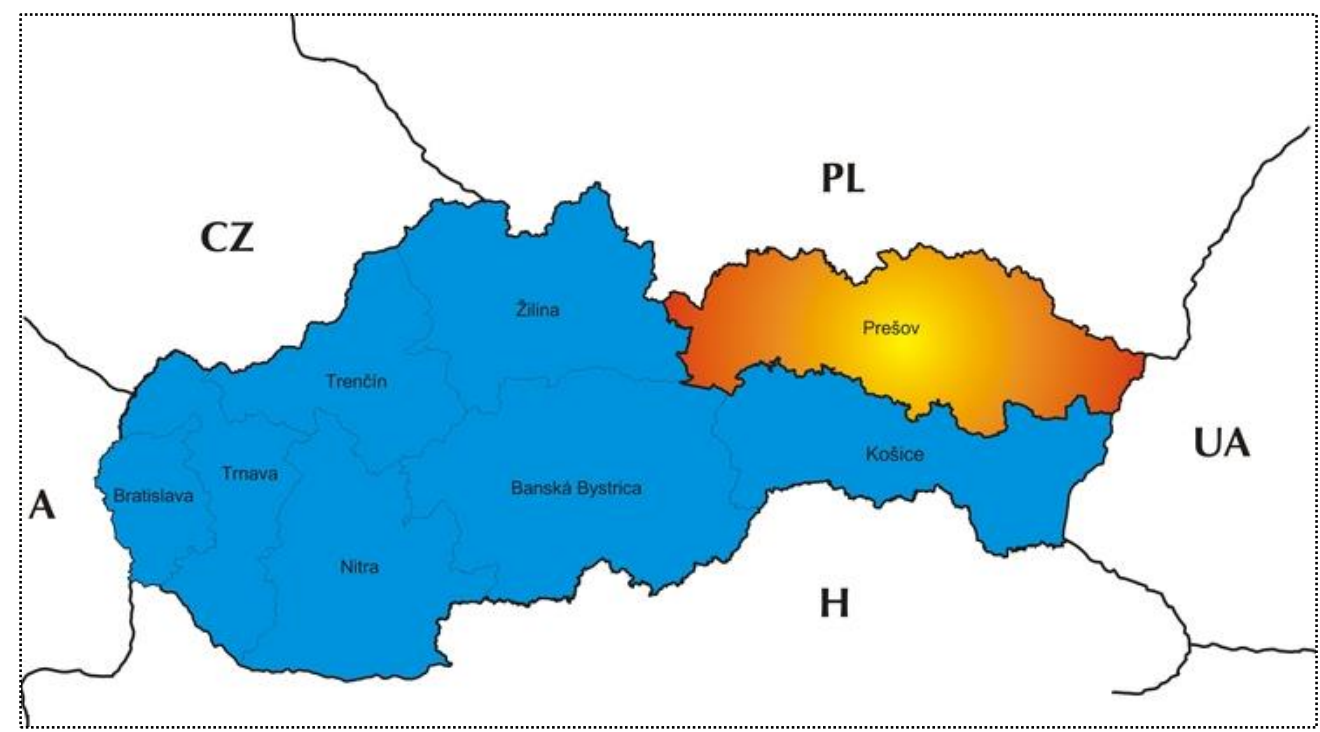

Fig. 2. The map of Presov Self - Governing Region

In Presov region, 816845 inhabitants are registered for permanent residence (dated until 31 December 2017), which is $15.03 \%$ of the population of the Slovak Republic. The third largest city in Slovakia - the Presov has 173,457 inhabitants. At the same time, the town belongs to the most populated communities in the Presov region.

\section{INVESTIGATION OF PREPAREDNESS FOR FLOOD PROTECTION}

A questionnaire survey was carried out in the municipality of Presov region. The questionnaires (in doc. format) were sent to a municipality representative with a request for their elaboration. As it is presented in Figure 3, in the Presov region, the totals of 662 questionnaires $(100 \%)$ were sent and $14.5 \%$ were completed (the questionnaires with partial answers were also included).

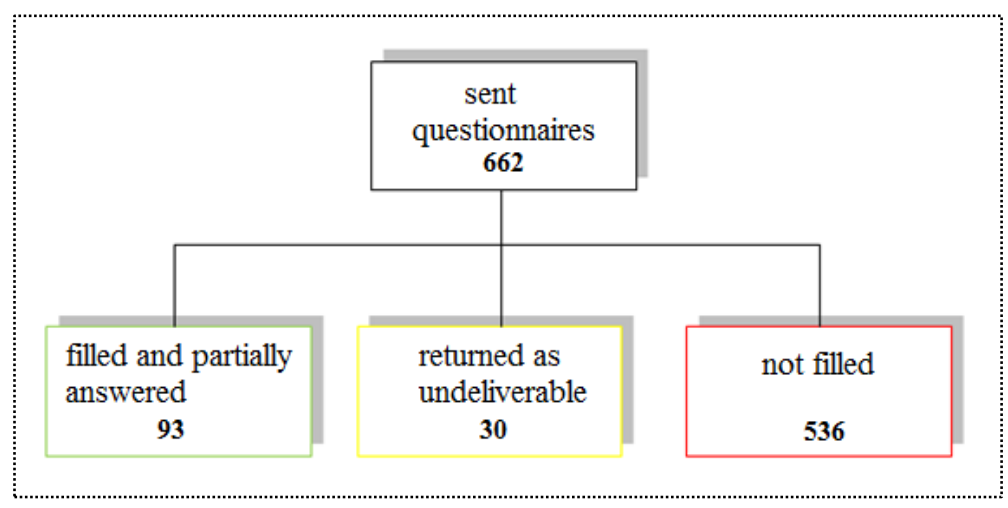

Fig. 3. The overall results of email correspondence in Presov region 
$4.53 \%$ of the questionnaire were returned as undeliverable (probably due to a technical error or malfunction of the Internet mailbox) and $80.97 \%$ were not completed.

In the months of October 2017 and February 2018 was distributed the questionnaire to all municipalities (more than 1100 emails in two rounds were sent) to all villages and towns in Presov region.

The questionnaire contained 28 questions aimed at general information as well as on flood protection measures. Six of them oriented on flood protection measures (current state, future implementation) are discussed in detail in this paper:

1. How many inhabitans are registered in your municipality?

2. Has the situation changed in your municipality during the last 10 years with regard to the flood protection?

3. Have been applied any flood protection measures in your municipality?

4. Do you think that your municipality should be flooded again in the future?

5 . Does your munucipality has prepared the plan of flood security work?

6. Does your munucipality has prepared the plan of flood rescue work?

\section{RESULTS AND DISCUSSION}

\subsection{Numbers of inhabitants}

The first question was concerned to the numbers of inhabitants living the municipalities in the Presov region. According to this question, the individual municipalities are divided into settlement units as follows:

$\checkmark$ rural village $(0-2,000$ inhabitants)

$\checkmark$ town $(2,000-100,000$ inhabitants)

$\checkmark \quad$ large city (more than 100, 000 inhabitants).

Based on these answers the graph presented in Figure 4 was done.

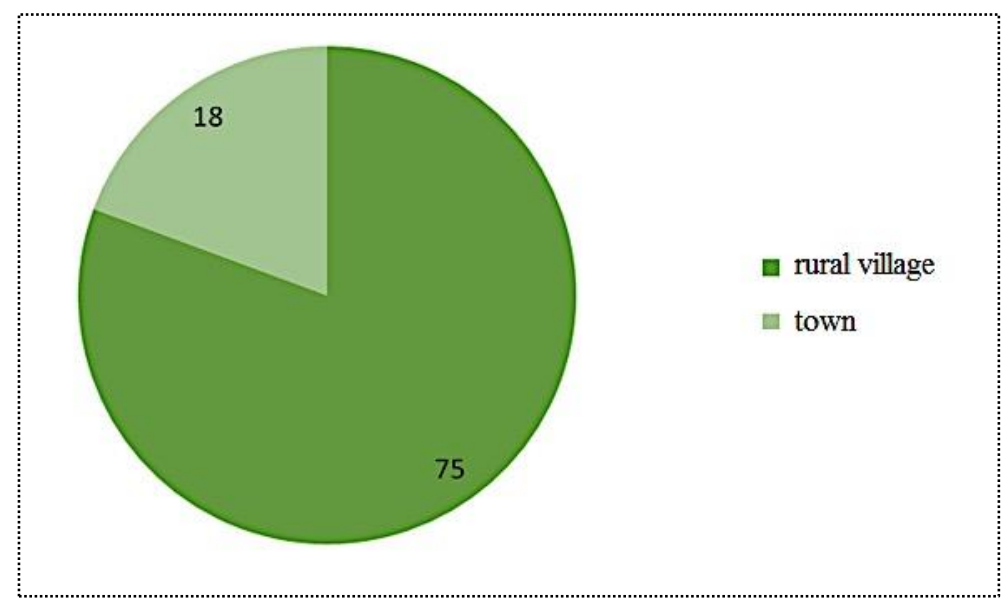

Fig. 4. The overall results of email correspondence in Presov region 
According to the Figure 4 it can be stated that 75 municipalities were classified as a town and 18 municipalities are rural villages. There is no large city in this region.

\subsection{Changes in the flood protection during the last 10 years}

All municipalities were asked to compare the situation with the floods in the villages and towns over the last 10 years due to the frequent occurrence of floods. The response options were as follows:

$\checkmark$ no answer

$\checkmark$ the situation get worsened

$\checkmark$ the situation has considerably worsened

$\checkmark$ the situation get better

$\checkmark$ the situation remained the same

$\checkmark$ I do not know

The overall results of the questionnaire according to the question about the changes in the flood protection measures are presented in Figure 5.

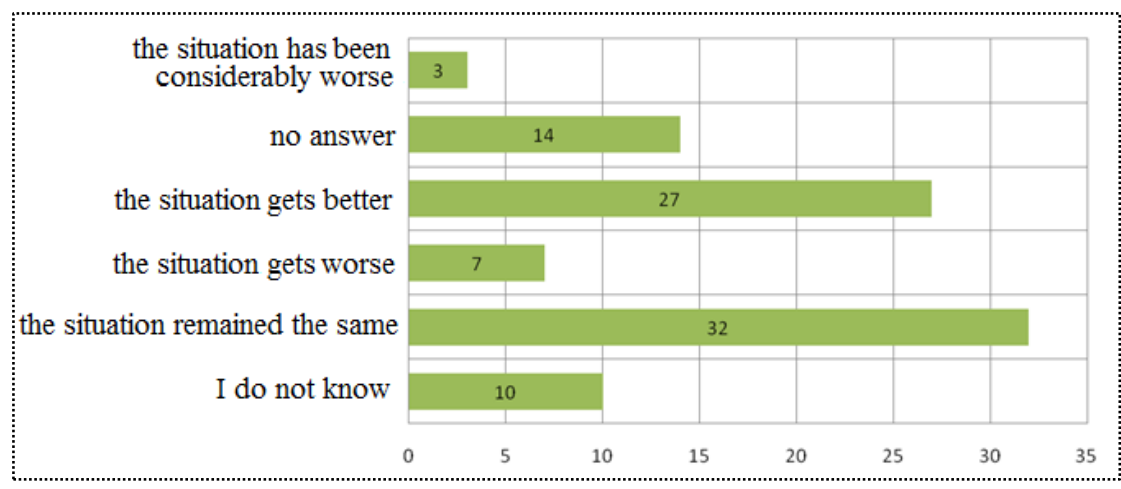

Fig. 5. The overall results the changes in the flood protection during the last 10 years of in Presov region

Considering the situation with regard to the frequent occurrence of floods 32 villages and towns (out of 93 questionnaires in total) confirmed that the situation remained the same. That the situation gets better was confirmed in 27 municipalities and in 10 questionnaires they did not answered the question. Situation gets worse in 7 cases and considerably worse in 3 municipalities.

\subsection{Implementation of flood the protection measures}

The current state of implementation of the flood control measures in the municipality was also investigated by the questionnaire. The answer was "yes" or "no" where 93 municipalities answered the question. A summary of the answers is shown in Figure 6.

68 municipalities responded "yes" (flood measures have already been implemented in their municipality) which correspond to $74.19 \%$ of respondents. No flood control measures have been implemented in 19 (20.43\%) municipalities and 6 municipalities have not answered the question (6.45\%). 


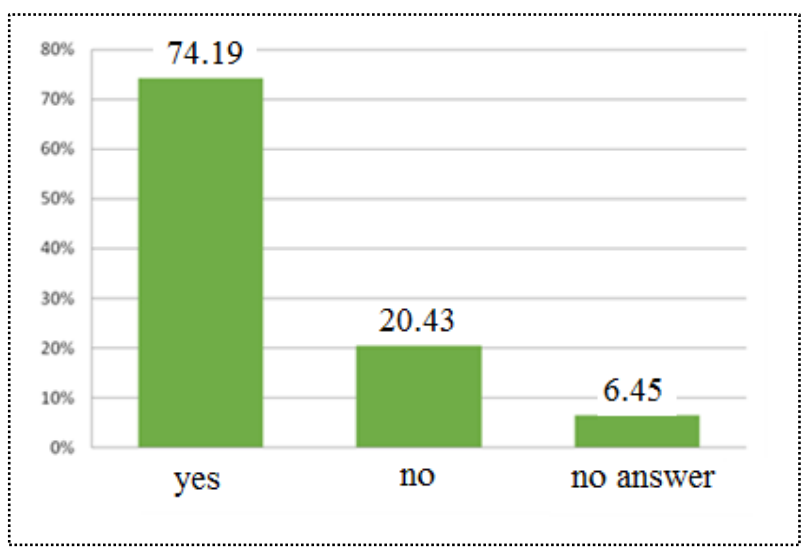

Fig. 6. Current state of implementation of flood control measures

\subsection{The aspect of the future floods}

The phenomenon of the floods often occurs in the Presov region. That is why one of the questions in the questionnaire was: "Do you think that your municipality should be flooded again in the future?". Individual answers in percentage are presentedin Figure 7.

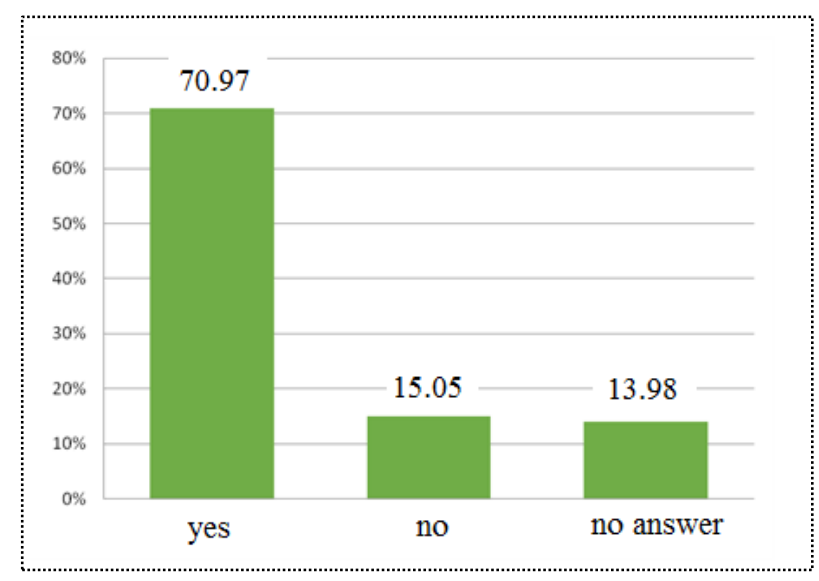

Fig. 7. The probability of the future floods

From the received answers presented in Fig. 7, in 66 municipalities people think that the flood situation will repeat, while in case of 14 villages and town they the flood situation seems improbable. In 13 questionnaires, the question about the future flood situation was not answered.

\subsection{The plans of flood security and flood rescue work}

The last part of the survey consists of assessment of preparedness to flood situation. Two types of plan should be prepared in the municipalities; plan of flood security work and plan of flood rescue work. Overview of received answers is depicted in Figure 8 and Figure 9. 


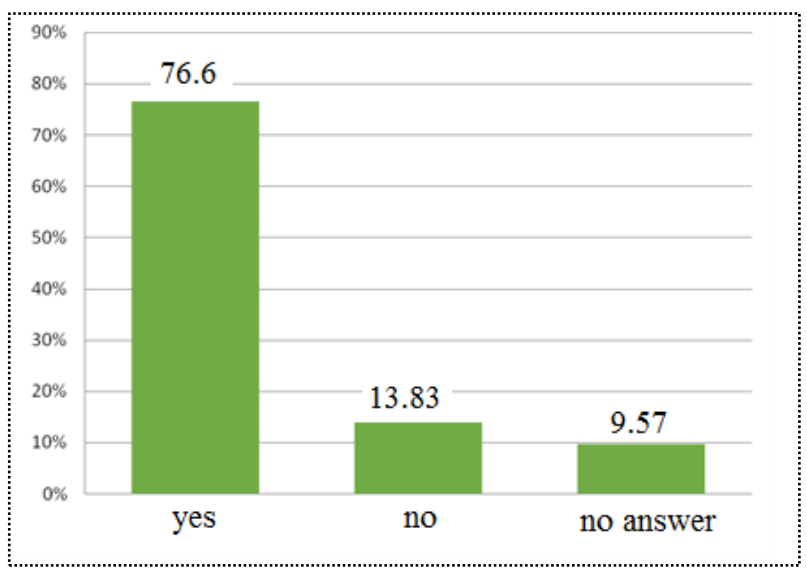

Fig. 8. Preparedness of the plan of the flood security work

In the Presov region from the received answers 72 municipalities has worked-out the plan of the flood security work and 13 municipalities has not. No response to this question was in case of 13 villages and towns.

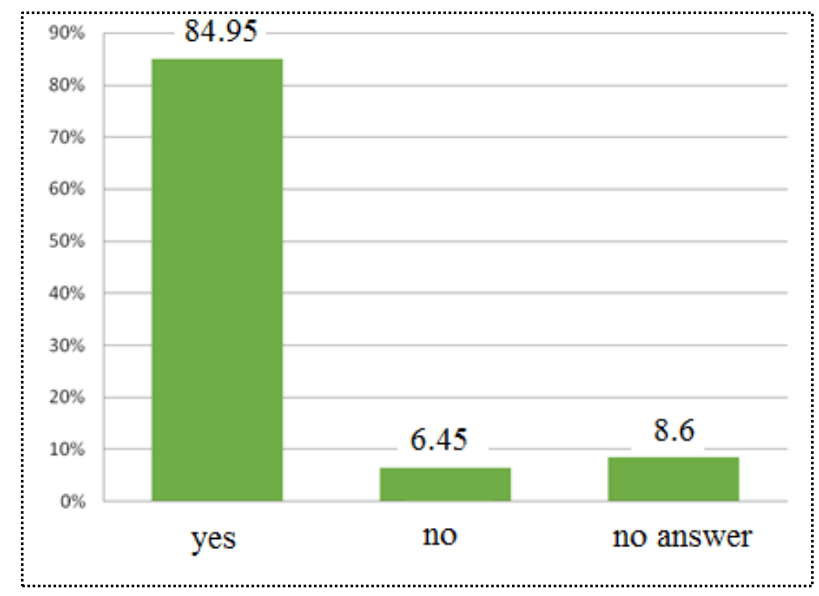

Fig. 9. Preparedness of the plan of the flood rescue work

In connection to the plan of the flood rescue work, from the received answers 79 municipalities has worked-out the plan and 6 municipalities has not. No response to this question was in case of 8 villages and towns.

\section{CONCLUSIONS}

The questionnaire survey was intended to help municipalities and to deepen knowledge level in the area of flood management in municipalities. Flood control measures are implemented as a combination of a whole range of measures, including 
flood forecasting and warning services. In the paper selected 6 questions (chosen from 28 of total questions of the questionnaire survey) were used to identify the preparedness for flood protection measures of municipalities in Presov region.

Based on the results obtained and the evaluations, the municipalities can make a significant contribution to increasing flood protection and flood prevention. The questionnaire survey was prepared with the aim to help to the municipalities and self-governments to deepen knowledge levels in the area of flood protection. Many of whom have expressed the interest in feedback - the results of the questionnaire survey to be sent to them. It means that it was worth to participate at this questionnaire survey. The field of flood protection the work cannot be stopped on the on the boundary of the cadastral area but it should also consider the adjacent river basins. It should be emphasized that reducing the risk of flooding increases the safety of people in the areas under consideration.

\section{ACKNOWLEDGEMENTS}

This work has been supported by the Slovak Research and Development Agency by supporting the project SK-PT-18-0008. This work has been supported by SKHU/1601/4.1/187 project.

\section{REFERENCES}

1. Blistanova M., Zelenakova M., Blistan, P., Ferencz, V. (2016), Assessment of flood vulnerability in Bodva river basin, Slovakia. Acta Montanistica Slovaca 21(1), 19-28.

2. EEA Report (2017), Green Infrastructure and Flood Mangement, Challenges related to flood risk requiring improved responses, Luxembourg: Publication Office of the European Union.

3. Frisco-project.eu (2019), Cross-border cooperation for flood risk reduction, Iterreg Slovenia-Croatia, Types of flood pretection measures, Accessed on 14. 01. 2019 https://frisco-project.eu/en/about-the-project/general-about-reducing-floodrisk/types-of-flood-protection-measures/

4. Glassey S. (2008), Managing flood rescue operations. Accessed on: https://www.researchgate.net/publication/324133241_Managing_flood_rescue_oper ations. Accessed on 14. 01. 2019.

5. Ministry of the Environment of the Slovak Republic, Analysis of the state of flood protection in the SR, Annex 2, 2010.

6. Ministry of the Environment of the Slovak Republic, Analysis of the state of flood protection in the SR, Annex 1 and Annex 2, 2013.

7. Ondrejka Harbulakova V., Lechman M., Zelenakova M. (2017), Flood Protection Measures in Slovakia - Polders. Edited by: Fialova, J., Pernicova, D. Public Recreation and Landscape Protection - With Nature Hand In Hand? Czech Soc Landscape Engineers; Mendel Univ Brno, 127-132.

8. Presov region. Map of the territory. https://www.po-kraj.sk/en/self-governing/ Accessed on 14. 01. 2019. 
9. Slovak Hydrometeorological Institute (SHMI), Flood situation in Slovakia during May and June 2010. Available on (in Slovak): http://www.shmu.sk/File/Povodnova_situacia_na_tokoch_vychodneho_Slovenska_v _maji_a_juni_2010_opravene1.pdf

10. Sugarekova $\bar{M}$. (2018), Preparation status of the municipalities on dealing with the flood protection, Bachelor thesis, TUKE:Kosice, p. 87.

11. Zelenakova M. (2011), Flood Risk Assessment and Management In Slovak Republic. Electronic Journal Of The Faculty Of Civil Engineering Osijek-E-Gfos 3, 113-119. 